\title{
建築設備の建物用途別ライフサイクル環境負荷原単位 LCI DATA ON ELECTRICAL AND MECHANICAL FACILITIES FOR VARIOUS KINDS OF BUILDINGS
}

\author{
伊香賀 俊治*，外 岡 豊** \\ Toshiharu IKAGA and Yutaka TONOOKA
}

\begin{abstract}
Environmental burdens through building life cycle are induced by almost all industries such as raw material manufacturers, fabricators, traders and other service industries. Better way to carry out LCA of building practically is to develop LCI data based on the 1990 inputoutput table and other statistical data. This paper describes $\mathrm{LCCO}_{2}, \mathrm{LCSOx}$ LCNOx, LCE and LCC data on electrical and mechanical facilities for 12 kinds of buildings such as offices, hotels, hospitals, stores, schools, universities, complex buildings, halls, logistics, factories, dormitories and apartments.
\end{abstract}

Keywords : Input-Output Table, Life Cycle Assessment, Environmental Burden, Building Facility 産業連関表、ライフサイクルアセスメント、環境負荷、建築設備

\section{1. はじめに}

建筑物は、多種多様な製品とサービスによって建設・運用され る一品生産品であり、設計初期段階に使える実用的な LCA 手法 と環境負荷原単位の整備が求められている。そのための有力な手 法のひとつとして、産業連関表 ${ }^{13)}$ 等の統計データを応用した研究 が、岡 6) 8)、酒井9)らにより取り組まれてきた。筆者らも1990年 度より始まった日本建築学会 建築と地球環境特別研究委員会で の活動を契機として、1985 年および 1990 年産業連関表等を利用 した環境負荷原単位の整備に取り組んできたところである ${ }^{2 \sim 4) 。 ~}$

筆者らは、既報 1において、建物規模別工事実績統計 ${ }^{17}$ 、1990 年産業連関表等の各種統計データを利用して、1995 年中に䇋エし た事務所ビルの電気・空調・衛生・昇降機設備のライフサイクル 各段階における㻴境負荷原単位 $\left(\mathrm{CO}_{2} 、 \mathrm{SO}\right.$ 、 $、 \mathrm{NO}$ x、一次エネ ルギー）およびコスト原単位の分析結果を報告した。本報では、 分析対象を1994〜1996年の3カ年中に竣工した 12 用途の建物 (事 務所、ホテル、病院、店舗、小中高校、大学、複合ビル、集会施 設、流通施設、工場、独身寮、集合住宅）に拡大した結果を報告 する。

\section{2. 罱境負荷原単位の作成方法 \\ 2.1 環境買荷原単位の分析境界}

環境負荷原単位の境界条件は、既報と同嵄に、日本国内及び海 外までの波及効果を含み、固定資本形成分を含むものとした。1990 年の 405 産業部閒別直接環境負荷 $\left(\mathrm{CO}_{2} 、 \mathrm{SOx} 、 \mathrm{NOx} 、\right.$ エネル

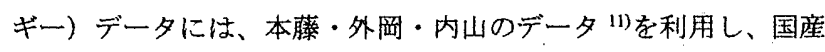
品に置き換えると誤差が大きい5品目（原油、LNG、石炭、アル ミ地金、鉄鉱石）の直接環境負荷を積上げ法で計上し、それ以外 の輸入品は国産品に置き換えて算出した。また、固定資本マトリ ックスを利用して、便宜的に製品・サービスの生産に必要な固定 資本(耐用年数 1 年以上か力購入価格 20 万円以上の建物、生産設 備等)分を含めた。さらに、流通段階産業連関表取引基本表の需要 合計欄に記載された各品目每の各流通産業への投入金額に、当該 部門の生産者価格あたりの環境負荷原単位を乗じて集計すること により、流通段階の環境負荷原単位を算出した。使用した購入者

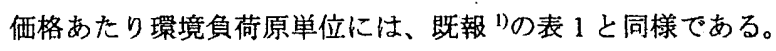

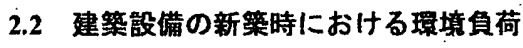

既報 1)では、工事原価分析情報（平成 7 年版） ${ }^{17}$ に記載されて いる 1995 年中に竣工した事務所ビル（111 件）について分析を行
* 東京大学生産技術研究所 助教授. 工博

** 埼玉大学経済学部社会環境設計学科 教授・工博
Assoc. Prof., Institute of Industrial Science, University of Tokyo, Dr. Eng. Prof., Dept. of Social Environment Planning, Faculty of Economics, Saitama University, Dr. Eng. 
つたが、本報では、表 1に示すように、1994〜1996 年の3力年中 に竣工した 12 用途の建物に分析対像を扡大した。これらの電気。 空謂・衛生・昇降機設備の延床面積あたり工事費（1990 年価格、 消費税別）を表 2 に示す。

規模別の電気・空調・衛生・昇降機の各設满工事細目金額に基 づき、建築工事標淮部掛等 ${ }^{19), 20)}$ を用いて、産業連関表の部門分類 に合うように細々目の割合を定め、産業連関表の行部門に割り付 けた。さらに、同統計資料に記載されている工期データに基づき 着工年を算出し、設備資機材等単価指数表 ${ }^{18)}$ を利用して 1990 年 価格に補正した。また、建設部門分析用産業連関表を利用して、 27 細目の建物用途別・構造別、排出起原別内訳付き環境負荷原単 位を算出し、凟機材製造および流通段階までの環境負荷を 1 とし た時の、それ以外の環境負荷の割合を求め、工事現場段階におけ る環境負荷を共通費分という工事細目に簡易計上した。

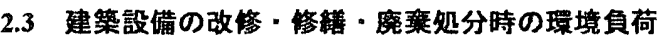

各種設備機器及び資材の更新周期（年）および修綪率（\%/年）

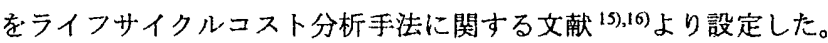
また、改修工事・修繒・廃衰姺分時に撤去される設備機器・資材・ 廃材の片道輸送距離を $30 \mathrm{~km}$ とし、車両積载率（最大積載重量に 対する奏際の積載重量の比率）を、容積が大きい割に重量が少な いものを0.6、重量が多いものを 0.8 と設定した。

評洒対象期間を 100 年とし、建替周期を 35 年、50 年、100 年等 を設定して、新築工事、建替工事、修繬、改修工事、廃谼処分段 階別の環境負荷原単位を算出した。なお、廃畗処分については、 修繥時、更新時、解体時に発生する廃材重量を基に、搬送分のみ を計上し、廃材処理(再生、焼却、埋立等)については検討対象外 とした。また、建築設備の運転（エネルギー消費）段階の環境負 荷も検討対象外とした。その他、計算条件は既報 ${ }^{1)}$ の表 2〜5と同 様である。

表 1 分析対象とした建榮物の件数と平均延床面積

\begin{tabular}{|c|c|c|c|c|c|c|c|c|c|c|c|c|c|}
\hline & 事務听 & $\begin{array}{l}\text { ホテル } \\
\text { •旅毁 } \\
\end{array}$ & $\begin{array}{l}\text { 病院・ } \\
\text { 診㞠所 }\end{array}$ & 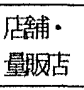 & $\begin{array}{l}\text { 小中 } \\
\text { 謧校 }\end{array}$ & $\begin{array}{c}\text { 大学. } \\
\text { 蔐専 }\end{array}$ & $\begin{array}{l}\text { 袘合 } \\
\text { ビル }\end{array}$ & $\begin{array}{l}\text { 集会 } \\
\text { 施監 }\end{array}$ & $\begin{array}{l}\text { 流甬 } \\
\text { 施改法 } \\
\end{array}$ & 工場 & 独身燎 & 集合 \\
\hline \multirow{2}{*}{ 件 } & $1000 \mathrm{~m}^{3}$ 末満 & 88 & 3 & 20 & 23 & 2 & 6 & 63 & 4 & 13 & 8 & 16 & 114 \\
\hline & $1000 \mathrm{~m}^{2}$ 以上 & 150 & 10 & 30 & 32 & 7 & 15 & 95 & 19 & 24 & 52 & 45 & 424 \\
\hline \multirow[t]{5}{*}{ 数 } & $3000 \mathrm{~m}^{2}$ 以上 & 60 & & 41 & 17 & 4 & 6 & 38 & 3 & 22 & 21 & 8 & 250 \\
\hline & $5000 \mathrm{~m}^{2}$ 以上 & 48 & 1 & 15 & 13 & 4 & 8 & 32 & 7 & 19 & 25 & 11 & 158 \\
\hline & $10000 \mathrm{~m}^{3}$ 以上 & 35 & & 2 & 10 & 2 & & 27 & & 11 & 12 & 1 & 58 \\
\hline & $30000 \mathrm{~m}^{3}$ 以上 & 7 & & & & & & 11 & & & & & 5 \\
\hline & 合 計 & 388 & 58 & 133 & 122 & 46 & 56 & 266 & 68 & 129 & 142 & 86 & 1015 \\
\hline \multicolumn{2}{|c|}{ 平均面積 $\left(\mathrm{m}^{2} / /\right.$ 件 $\left.^{\prime}\right)$} & 4568 & 3943 & 3326 & 5242 & 4540 & 4091 & 5866 & 3050 & 7911 & 5519 & 2859 & 4017 \\
\hline
\end{tabular}

表 2 延床面䱦あたり設備工事費（千円 $/ \mathrm{m}^{2} ）$ 共通費含む、消費税別、1990 年洒格

\begin{tabular}{|c|c|c|c|c|c|c|c|c|c|c|c|c|c|}
\hline & 事務所 & $\begin{array}{l}\text { ホテル } \\
\text { •族館 }\end{array}$ & $\begin{array}{l}\text { 病院・ } \\
\text { 馀听 }\end{array}$ & 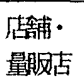 & $\begin{array}{l}\text { 小中 } \\
\text { 䯬交 }\end{array}$ & $\begin{array}{l}\text { 大学. } \\
\text { 高專 }\end{array}$ & $\begin{array}{l}\text { 複合 } \\
\text { ビル }\end{array}$ & $\begin{array}{l}\text { 集会 } \\
\text { 施段 }\end{array}$ & $\begin{array}{l}\text { 流通 } \\
\text { 施設行 }\end{array}$ & 工場 & 独身寮 & $\begin{array}{l}\text { 集合 } \\
\text { 住宅 }\end{array}$ \\
\hline \multirow{7}{*}{$\begin{array}{l}\text { 電 } \\
\text { 気 } \\
\text { 媛 } \\
\end{array}$} & 全規模 & 42.39 & 39.00 & 31.22 & 19.41 & 27.00 & 29.98 & 34.11 & 34.77 & 11.01 & 19.68 & 28.09 & 14.92 \\
\hline & $1000 \mathrm{~m}^{2}$ 未满 & 30.57 & 47.18 & 35.64 & 35.81 & 15.36 & 33.18 & 26.70 & 37.54 & 24.99 & 43.64 & 29.10 & 17.79 \\
\hline & $1000 \mathrm{~m}^{2}$ 以上 & 31.43 & 39.67 & 34.38 & 24.64 & 31.85 & 33.29 & 27.12 & 31.20 & 13.92 & 19.00 & 27.39 & 15.10 \\
\hline & $3000 \mathrm{~m}^{2}$ 以上 & 34.61 & & 32.65 & 19.77 & 39.63 & 23.71 & 28.31 & 39.94 & 10.72 & 21.09 & 23.50 & 13.95 \\
\hline & $5000 \mathrm{~m}^{2}$ 以上 & 37.96 & 22.70 & 28.80 & 11.92 & 26.54 & 30.94 & 28.03 & 27.87 & 10.41 & 19.83 & 31.13 & 12.86 \\
\hline & $10000 \mathrm{~m}^{2}$ 以上 & 45.29 & & 21.63 & 13.55 & 5.43 & & 32.71 & & 8.94 & 13.48 & 29.40 & 15.70 \\
\hline & $30000 \mathrm{~m}^{2}$ 以上 & 53.41 & & & & & & 38.33 & & & & & 20.28 \\
\hline \multirow{7}{*}{$\begin{array}{l}\text { 空 } \\
\text { 調 } \\
\text { 設 } \\
\text { 備 }\end{array}$} & 全規模 & 42.47 & 36.89 & 29.79 & 16.63 & 23.19 & 37.20 & 33.68 & 32.16 & 6.49 & 17.71 & 16.53 & 4.96 \\
\hline & $1000 \mathrm{~m}^{2}$ 未满 & 22.07 & 41.48 & 31.76 & 23.59 & 7.55 & 26.40 & 18.17 & 46.46 & 27.11 & 17.03 & 10.91 & 9.97 \\
\hline & $1000 \mathrm{~m}^{2}$ 以上 & 28.47 & 29.34 & 34.99 & 17.48 & 19.29 & 41.23 & 20.72 & 32.97 & 5.83 & 13.31 & 16.03 & 4.99 \\
\hline & $3000 \mathrm{~m}^{2}$ 以上 & 36.68 & & 32.91 & 17.92 & 40.40 & 36.75 & 23.52 & 50.16 & 5.44 & 16.91 & 13.35 & 4.50 \\
\hline & $5000 \mathrm{~m}^{2}$ 以上 & 45.23 & 34.12 & 27.92 & 10.43 & 17.29 & 34.52 & 27.67 & 29.41 & 5.01 & 20.08 & 16.67 & 3.94 \\
\hline & $10000 \mathrm{~m}^{2}$ 以上 & 49.18 & & 26.87 & 10.42 & 10.23 & & 33.64 & & 6.88 & 8.92 & 21.88 & 4.89 \\
\hline & $30000 \mathrm{~m}^{2}$ 以上 & 40.26 & & & & & & 27.52 & & & & & 2.25 \\
\hline \multirow{7}{*}{$\begin{array}{l}\text { 衛 } \\
\text { 生 } \\
\text { 設 } \\
\text { 備 }\end{array}$} & 全規模 & 18.76 & 33.97 & 32.52 & 11.66 & 17.65 & 14.84 & 20.15 & 21.10 & 5.42 & 10.23 & 26.69 & 19.73 \\
\hline & $1000 \mathrm{~m}^{2}$ 末满 & 18.67 & 37.04 & 33.71 & 16.76 & 2.77 & 16.39 & 21.26 & 19.37 & 10.77 & 21.69 & 33.91 & 24.70 \\
\hline & $1000 \mathrm{~m}^{2}$ 以上 & 15.85 & 43.51 & 37.69 & 13.02 & 21.51 & 17.57 & 19.86 & 20.41 & 7.90 & 11.39 & 26.74 & 21.40 \\
\hline & $3000 \mathrm{~m}^{2}$ 以上 & 15.08 & & 31.28 & 12.87 & 4.70 & 11.07 & 20.91 & 33.22 & 4.28 & 8.19 & 26.58 & 19.85 \\
\hline & $5000 \mathrm{~m}^{2}$ 以上 & 15.63 & 21.28 & 29.59 & 8.07 & 17.76 & 15.21 & 18.08 & 16.30 & 5.69 & 10.64 & 26.20 & 18.38 \\
\hline & $10000 \mathrm{~m}^{2}$ 以上 & 18.96 & & 24.47 & 6.88 & 4.98 & & 17.48 & & 4.80 & 4.80 & 25.97 & 18.19 \\
\hline & $30000 \mathrm{~m}^{2}$ 以上 & 25.05 & & & & & & 19.52 & & & & & 7.54 \\
\hline \multirow{7}{*}{$\begin{array}{l}\text { 暴 } \\
\text { 格 } \\
\text { 譏 } \\
\text { 䚚 }\end{array}$} & 全規模 & 9.40 & 2.62 & 1.96 & 4.04 & 0.64 & 1.54 & 2.71 & 1.07 & 2.62 & 1.35 & 1.13 & 3.76 \\
\hline & $1000 \mathrm{~m}^{2}$ 末満 & 9.30 & 1.24 & 2.46 & 2.73 & & 2.14 & 3.17 & 0.66 & 2.92 & 1.56 & 0.80 & 5.50 \\
\hline & $1000 \mathrm{~m}^{2}$ 以上 & 7.10 & 1.26 & 2.11 & 2.99 & 0.62 & 0.85 & 2.80 & 0.74 & 2.43 & 1.57 & 0.93 & 4.85 \\
\hline & $3000 \mathrm{~m}^{2}$ 以上 & 10.03 & & 1.85 & 4.05 & 0.81 & 0.89 & 2.71 & 0.34 & 1.99 & 1.58 & 1.25 & 3.56 \\
\hline & $5000 \mathrm{~m}^{2}$ 以上 & 10.19 & 1.93 & 1.59 & 1.64 & 0.51 & 0.73 & 2.82 & 0.52 & 1.69 & 1.02 & 1.38 & 2.89 \\
\hline & $10000 \mathrm{~m}^{2}$ 以上 & 11.20 & & 0.78 & 5.53 & 0.41 & & 2.88 & & 1.76 & 1.62 & 1.62 & 3.51 \\
\hline & $30000 \mathrm{~m}^{2}$ 以上 & 5.86 & & & & & & 2.43 & & & & & 4.50 \\
\hline
\end{tabular}


3. 環境負荷原単位の算出結果と考察

\section{1 建築設備の新策工事段階までの環境負荷原単位}

電気設備の機器・資材製造から新筑工事段階までの床面積あた り $\mathrm{CO}_{2}$ 原単位を表 3 に示す。全規模合計値では、最も小さい流通 施設の $28.60 \mathrm{~kg}-\mathrm{CO}_{2} / \mathrm{m}^{2}$ から最も大きい事務所の $116.14 \mathrm{~kg}-\mathrm{CO}_{2} /$ $\mathrm{m}^{2}$ まで約 4 倍の違いがある。事務所及び複合ビルの $\mathrm{CO}_{2}$ 排出量は、 大規模になるほど大きくなっているが、その他の用途については 規模による明確な傾向は読み取れない。工事細目に着目寸ると、 共通費分に次いで、照明器具、盤類、配管材、变電設備が大きな 割合を占めていることが全用途に共通している。

表 3 電氮設備の新築工事段陼まで延床面積あたり $\mathrm{CO}_{2}$ 排出量 $\left(\mathrm{kg}-\mathrm{CO}_{2} / \mathrm{m}^{3}\right)$

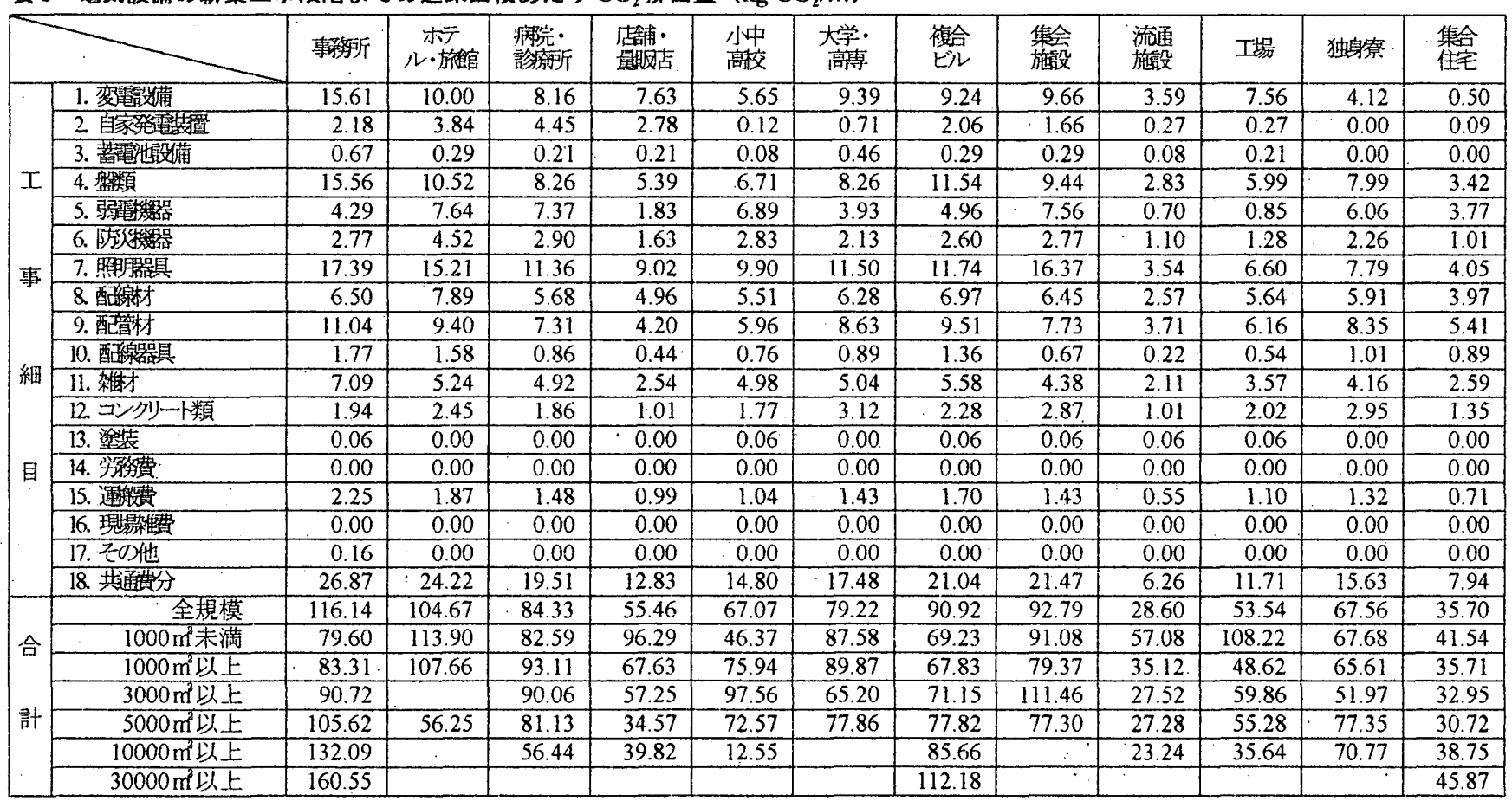

表 4 空調設備の新築工事段階までの延床面樌あたり $\mathrm{CO}_{2}$ 排出量 $\left(\mathrm{kg}-\mathrm{CO}_{2} / \mathrm{m}^{2}\right)$

\begin{tabular}{|c|c|c|c|c|c|c|c|c|c|c|c|c|c|}
\hline & 事務所 & $\begin{array}{l}\text { ホテル } \\
\text { •旗绾 }\end{array}$ & $\begin{array}{l}\text { 病院. } \\
\text { 馀㞠所 }\end{array}$ & 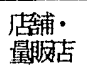 & $\begin{array}{l}\text { 小中 } \\
\text { 高校 }\end{array}$ & $\begin{array}{c}\text { 大学. } \\
\text { 高軎 }\end{array}$ & $\begin{array}{l}\text { 襍合 } \\
\text { ビル }\end{array}$ & 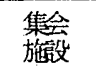 & $\begin{array}{l}\text { 流通 } \\
\text { 施没没 }\end{array}$ & 工場 & 独身尞 & $\begin{array}{l}\text { 集合 } \\
\text { 住宅 }\end{array}$ \\
\hline \multirow{7}{*}{$I$} & 1. ボイ類 & 0.08 & 4.53 & 0.89 & 0.00 & 0.16 & 0.36 & 0.04 & 1.46 & 0.00 & 0.24 & 0.00 & 0.04 \\
\hline & 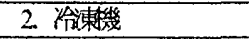 & 1.47 & 6.22 & 3.44 & 0.73 & 3.02 & 4.25 & 0.74 & 1.66 & 0.19 & 1.24 & 0.00 & 0.00 \\
\hline & 3. 椧告搭 & 0.23 & 1.16 & 0.50 & 0.19 & 0.19 & 1.01 & 0.23 & 0.16 & 0.04 & 0.19 & 0.00 & 0.00 \\
\hline & 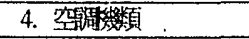 & 50.39 & 25.55 & 33.31 & 18.71 & 20.33 & 41.24 & 35.94 & 28.95 & 6.92 & 15.34 & 18.63 & 2.47 \\
\hline & 5. ポ フ類 & 0.25 & 1.14 & 0.35 & 0.15 & 0.30 & 0.40 & 0.50 & 0.40 & 0.05 & 0.15 & 0.05 & 0.05 \\
\hline & 6. ファ類 & 5.18 & 4.48 & 3.52 & 2.82 & 3.17 & 2.86 & 7.00 & 6.07 & 2.20 & 6.38 & 4.52 & 2.36 \\
\hline & 7. 製類 & 0.75 & 2.83 & 1.33 & 0.23 & 1.79 & 0.87 & 0.29 & 0.81 & 0.06 & 0.75 & 0.06 & 0.06 \\
\hline \multirow{3}{*}{ 軩 } & 8. ダク類 & 5.46 & 3.99 & 2.52 & 2.33 & 3.00 & 4.66 & 4.66 & 5.52 & 0.67 & 2.66 & 1.80 & 1.14 \\
\hline & 9. 配管材 & 11.17 & 12.06 & 9.17 & 5.33 & 8.41 & 12.38 & 8.27 & 9.84 & 2.16 & 4.21 & 3.87 & 1.00 \\
\hline & 10. 自重件珤 & 6.57 & 9.74 & 6.41 & 1.32 & 5.74 & 8.44 & 3.40 & 6.05 & 0.52 & 2.60 & 1.06 & 0.00 \\
\hline \multirow{4}{*}{ 細 } & 11. 制览吅類 & 6.52 & 4.96 & 3.60 & 2.48 & 2.63 & 4.77 & 5.35 & 5.06 & 1.27 & 2.34 & 2.14 & 1.12 \\
\hline & 12. 弁、計器 雑金物類 & 2.63 & 4.58 & 2.39 & 1.07 & 1.85 & 3.55 & 1.75 & 2.00 & 0.20 & 1.22 & 0.49 & 0.29 \\
\hline & 13. 雑才 & 1.71 & 1.36 & 1.51 & 0.91 & 2.62 & 1.66 & 1.51 & 1.36 & 0.25 & 0.91 & 0.66 & 0.25 \\
\hline & 14. コンクリート類 & 1.10 & 2.95 & 0.68 & 0.84 & 0.68 & 0.51 & 0.51 & 0.34 & 0.17 & 0.25 & 0.42 & 0.17 \\
\hline \multirow[t]{6}{*}{ 目 } & 15. 保昷 登装 & 4.14 & 4.14 & 2.49 & 1.66 & 2.07 & 3.73 & 3.31 & 3.31 & 0.42 & 1.66 & 1.66 & 0.42 \\
\hline & 16. 労袎費 & 0.00 & 0.00 & 0.00 & 0.00 & 0.00 & 0.00 & 0.00 & 0.00 & 0.00 & 0.00 & 0.00 & 0.00 \\
\hline & 17. 運艘费 & 2.09 & 1.92 & 1.26 & 0.93 & 0.93 & 1.70 & 1.65 & 1.15 & 0.38 & 1.04 & 0.99 & 0.28 \\
\hline & 18. 現易椎費 & 0.00 & 0.00 & 0.00 & 0.00 & 0.00 & 0.00 & 0.00 & 0.00 & 0.00 & 0.00 & 0.00 & 0.00 \\
\hline & 19. 完两他 & 0.48 & 0.00 & 0.00 & 0.00 & 0.00 & 0.00 & 0.00 & 0.00 & 0.00 & 0.00 & 0.00 & 0.00 \\
\hline & 20. 共通費分 & 30.17 & 27.58 & 22.08 & 11.95 & 16.09 & 26.14 & 22.62 & 22.31 & 4.34 & 11.53 & 10.94 & 2.76 \\
\hline \multirow{4}{*}{ 合 } & 全規模 & 130.39 & 119.19 & 95.43 & 51.66 & 72.96 & 118.53 & 97.75 & 96.43 & 19.83 & 52.70 & 47.28 & 12.39 \\
\hline & $1000 \mathrm{~m}^{2}$ 末满 & 65.65 & 129.34 & 93.21 & 72.57 & 22.77 & 77.84 & 52.04 & 160.86 & 74.31 & 45.35 & 30.79 & 27.51 \\
\hline & $1000 \mathrm{~m}^{2}$ 以上 & 86.24 & 100.28 & 111.04 & 51.88 & 54.64 & 130.33 & 57.32 & 94.56 & 17.70 & 38.68 & 44.18 & 12.25 \\
\hline & $3000 \mathrm{~m}^{2}$ 以上 & 107.16 & & 108.68 & 57.42 & 121.74 & 115.81 & 64.40 & 142.25 & 15.42 & 51.26 & 37.57 & 10.63 \\
\hline \multirow{3}{*}{ 計 } & $5000 \mathrm{~m}^{2}$ 以上 & 136.44 & 97.39 & 93.01 & 35.17 & 53.02 & 113.21 & 81.64 & 84.13 & 14.60 & 60.21 & 46.71 & 9.19 \\
\hline & $10000 \mathrm{~m}^{2}$ W上 & 148.36 & & 80.43 & 33.45 & 34.36 & & 97.87 & & 20.37 & 26.75 & 70.25 & 11.51 \\
\hline & $30000 \mathrm{~m}^{2}$ WE & 124.51 & & & & & & 88.48 & & & & & 6.85 \\
\hline
\end{tabular}


空調設備の機器・凟材製造から新筑工事段階までの床面積あた り $\mathrm{CO}_{2}$ 原単位を表 4 に示す。全規模合計值では集合住宅が $12.39 \mathrm{~kg}$ - $\mathrm{CO}_{2} / \mathrm{m}^{2}$ 最小であるが、これは住戸内のルームエアコンや暖房 器具などが一般的に備品であるためと考えられる。最も大きいの は事務所の $130.39 \mathrm{~kg}-\mathrm{CO}_{2} / \mathrm{m}$ であり、 $\mathrm{CO}_{2}$ 原単位に約 10 倍の差が ある。工事細目に着目すると空調機類の比率が最も大きいが、こ れは空調機だけでなく、ルームエアコン、パッケージェアコン、 ファンコイルユニット、可変風量装置などがここに分類されてい ることによる。

衛生設備の機器・資材製造から新筑工事段階までの床面積あた り $\mathrm{CO}_{2}$ 原単位を表 5 に示す。全規模合計值で最も大きいのはホテ ルの $138.40 \mathrm{~kg}-\mathrm{CO}_{2} / \mathrm{m}$ であり、それに次いで、病院・診療所、独 身寮、集合住宅が大きくなっている。最も小さいのは流通施設の $19.94 \mathrm{~kg}-\mathrm{CO}_{2} / \mathrm{m}^{2}$ であり、 $\mathrm{CO}_{2}$ 原単位に約 7 倍の差がある。工事細
目別には、鋼管・鋳鉄管類（給水・給湯・排水・消火配管）が共 通費分と並んで最も大きい。

昇降機設備の機器・資材製造から新築工事段階までの床面積あ たり $\mathrm{CO}_{2}$ 原単位を表 6 に示す。全規模合計値では、最も小さい小 中高校の $0.76 \mathrm{~kg}-\mathrm{CO}_{2} / \mathrm{m}^{2}$ から最も大きい事務所の $11.34 \mathrm{~kg}-\mathrm{CO}_{2} /$ mまで約 15 倍の違いがあり、規模による明確な傾向も読み取れな い。年降機については階数による影薌が大きいものと考えられる。

全 12 建物用途・全規模のデータを対象として、床面積あたりの 工事単価（消費税別・1990年価格）と新築工事段階までの僢境負 荷原単位の回帰分析を行った結果を表 7 に示す。確実度係数 $\mathrm{r}^{2}$ 值（ピアソンの積率相関係数を 2 乗した值）は、いずれの場合も 0.96 以上であり、建築設備の新築工事段階までの環境負荷原単位 は、建物用途・建物規模によらず、各設備工事単価に比例するこ とを示している。

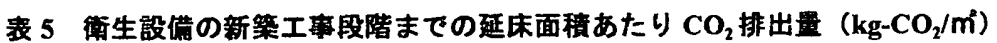

\begin{tabular}{|c|c|c|c|c|c|c|c|c|c|c|c|c|c|}
\hline & 事務所 & $\begin{array}{l}\text { ホテル } \\
\text { 旅館 }\end{array}$ & $\begin{array}{l}\text { 病院· } \\
\text { 馀部 }\end{array}$ & 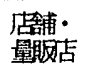 & 少中 & $\begin{array}{c}\text { 大学. } \\
\text { 高專 }\end{array}$ & $\begin{array}{l}\text { 複合 } \\
\text { ビル }\end{array}$ & $\begin{array}{l}\text { 集会 } \\
\text { 施設 }\end{array}$ & $\begin{array}{l}\text { 流通 } \\
\text { 施設 }\end{array}$ & 工場 & 独身竂 & 集合 \\
\hline \multirow{7}{*}{ I } & 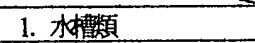 & 5.96 & 9.60 & 6.76 & 3.11 & 3.17 & 3.06 & 5.39 & 4.97 & 1.06 & 3.04 & 5.70 & 4.40 \\
\hline & 2. 聇洤類 & 0.29 & 6.36 & 3.18 & 0.23 & 0.35 & 0.41 & 0.35 & 1.97 & 0.06 & 0.52 & 1.45 & 0.12 \\
\hline & 3. ポ類 & 3.51 & 4.50 & 3.96 & 1.53 & 2.92 & 1.78 & 3.07 & 4.06 & 0.84 & 1.73 & 2.77 & 1.98 \\
\hline & 4. ボイラ類 & 2.88 & 6.78 & 5.62 & 0.77 & 1.30 & 1.10 & 3.98 & 1.83 & 0.48 & 0.92 & 9.60 & 7.33 \\
\hline & 5. 衛泩㗊具 & 6.54 & 8.33 & 9.82 & 2.78 & 5.04 & 4.44 & 5.51 & 5.30 & 1.11 & 1.88 & 5.25 & 5.12 \\
\hline & 6. 消栓 & 1.31 & 2.24 & 0.63 & 0.68 & 1.36 & 1.31 & 1.46 & 1.27 & 1.02 & 1.41 & 0.88 & 0.83 \\
\hline & 7. 特殊消火钤不 & 3.31 & 7.40 & 12.75 & 6.04 & 0.29 & 0.93 & 3.70 & 3.55 & 1.02 & 1.22 & 0.44 & 0.78 \\
\hline \multirow[t]{3}{*}{ 事 } & 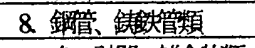 & 16.44 & 37.16 & 30.36 & 9.93 & 18.37 & 17.42 & 18.59 & 16.93 & 5.11 & 11.01 & 27.86 & 22.81 \\
\hline & 9. 弁、計器 雑銓物類 & 2.82 & 6.33 & 4.43 & 1.75 & 2.58 & 2.29 & 3.26 & 3.85 & 0.68 & 1.51 & 5.35 & 3.60 \\
\hline & 10. 雑才 & 1.16 & 1.61 & 1.97 & 0.71 & 1.97 & 1.01 & 1.21 & 1.61 & 0.30 & 0.71 & 1.26 & 1.16 \\
\hline \multirow[t]{3}{*}{ 細 } & 11. コソクリート類 & 3.80 & 5.40 & 8.43 & 3.12 & 4.89 & 4.22 & 3.63 & 6.33 & 2.11 & 3.46 & 6.66 & 3.88 \\
\hline & 12. 保昷 淦装 & 1.24 & 3.31 & 2.49 & 0.42 & 1.24 & 1.24 & 1.24 & 1.66 & 0.42 & 0.83 & 2.07 & 1.24 \\
\hline & 13. カxス工事 & 1.92 & 3.90 & 4.71 & 1.67 & 3.58 & 3.18 & 4.53 & 2.18 & 0.27 & 0.58 & 6.31 & 6.58 \\
\hline \multirow{6}{*}{ 目 } & 14. 労務費 & 0.00 & 0.00 & 0.00 & 0.00 & 0.00 & 0.00 & 0.00 & 0.00 & 0.00 & 0.00 & 0.00 & 0.00 \\
\hline & 15. 運船費 & 0.99 & 1.70 & 1.48 & 0.60 & 0.93 & 0.82 & 0.99 & 1.48 & 0.28 & 0.55 & 1.81 & 0.99 \\
\hline & 16. 現暢倠費 & 0.00 & 0.00 & 0.00 & 0.00 & 0.00 & 0.00 & 0.00 & 0.00 & 0.00 & 0.00 & 0.00 & 0.00 \\
\hline & 17. 引迈㛐費 & 2.04 & 1.77 & 1.77 & 1.15 & 0.45 & 0.63 & 2.22 & 1.28 & 0.83 & 0.50 & 2.74 & 1.41 \\
\hline & 18 z他 & 0.30 & 0.00 & 0.00 & 0.00 & 0.00 & 0.00 & 0.00 & 0.00 & 0.00 & 0.00 & 0.00 & 0.00 \\
\hline & 19. 共通歵分 & 16.40 & 32.02 & 29.61 & 10.38 & 13.71 & 12.40 & 17.80 & 17.53 & 4.36 & 8.36 & 24.13 & 17.80 \\
\hline \multirow{4}{*}{ 合 } & 全規模 & 70.90 & 138.40 & 127.97 & 44.85 & 62.15 & 56.23 & 76.92 & 75.78 & 19.94 & 38.20 & 104.28 & 80.01 \\
\hline & $1000 \mathrm{~m}^{2}$ 末満 & 68.29 & 128.45 & 116.05 & 59.89 & 11.32 & 59.32 & 76.54 & 72.43 & 31.73 & 83.16 & 132.64 & 92.68 \\
\hline & $1000 \mathrm{~m}^{2}$ 以上 & 60.46 & 181.25 & 140.03 & 50.01 & 63.69 & 62.89 & 73.29 & 71.37 & 30.31 & 40.76 & 100.82 & 85.33 \\
\hline & $3000 \mathrm{~m}^{3}$ 以上 & 54.97 & & 128.78 & 52.66 & 14.67 & 42.87 & 81.38 & 129.17 & 15.88 & 31.94 & 105.16 & 81.21 \\
\hline \multirow{3}{*}{ 計 } & $5000 \mathrm{~m}^{2}$ 以上 & 58.65 & 75.23 & 122.46 & 30.72 & 65.65 & 57.29 & 70.31 & 57.72 & 19.92 & 40.16 & 105.20 & 75.94 \\
\hline & $10000 \mathrm{~m}^{2}$ 以上 & 68.31 & & 117.79 & 26.75 & 20.36 & & 64.65 & & 17.75 & 18.57 & 86.61 & 74.92 \\
\hline & $30000 \mathrm{~m}^{2}$ 以上 & 94.77 & & & & & & 76.01 & & & & & 31.99 \\
\hline
\end{tabular}

\section{表 6 算降譏設借の新築工事段陵までの延床面積あたり $\mathrm{CO}_{2}$ 排出量 $\left(\mathrm{kg}-\mathrm{CO}_{2} / \mathrm{m}^{2}\right)$}

\begin{tabular}{|c|c|c|c|c|c|c|c|c|c|c|c|c|c|}
\hline \multicolumn{2}{|c|}{ 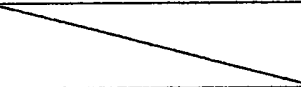 } & 事砣所 & $\begin{array}{l}\text { ホテル } \\
\text { •斿館 }\end{array}$ & $\begin{array}{l}\text { 病院· } \\
\text { 馀新 }\end{array}$ & $\begin{array}{l}\text { 店舗・ } \\
\text { 量䐓店 }\end{array}$ & $\begin{array}{l}\text { 小中 } \\
\text { 颤校 }\end{array}$ & $\begin{array}{c}\text { 大学. } \\
\text { 高専 }\end{array}$ & $\begin{array}{l}\text { 複合 } \\
\text { ビル }\end{array}$ & $\begin{array}{l}\text { 集会 } \\
\text { 施能 }\end{array}$ & $\begin{array}{l}\text { 流通 } \\
\text { 施䛌設 }\end{array}$ & 工場 & 独身尞 & 集合 \\
\hline \multirow{3}{*}{ 細 } & 1. 機器 & 8.71 & 2.37 & 1.77 & 3.71 & 0.59 & 1.38 & 2.48 & 0.95 & 2.41 & 1.22 & 1.03 & 3.43 \\
\hline & 2 労称費 & 0.00 & 0.00 & 0.00 & 0.00 & 0.00 & 0.00 & 0.00 & 0.00 & 0.00 & 0.00 & 0.00 & 0.00 \\
\hline & 3. 共通費分 & 2.62 & 0.71 & 0.53 & 1.12 & 0.17 & 0.39 & 0.75 & 0.29 & 0.67 & 0.34 & 0.31 & 0.98 \\
\hline \multirow{4}{*}{ 含 } & 全規模 & 11.34 & 3.08 & 2.31 & 4.82 & 0.76 & 1.77 & 3.23 & 1.23 & 3.08 & 1.56 & 1.33 & 4.41 \\
\hline & $1000 \mathrm{~m}^{2}$ 末満 & 10.93 & 1.44 & 2.87 & 3.23 & 0.00 & 2.48 & 3.74 & 0.77 & 3.38 & 1.77 & 0.92 & 6.39 \\
\hline & $1000 \mathrm{~m}^{2}$ 以上 & 8.41 & 1.49 & 2.46 & 3.49 & 0.71 & 0.96 & 3.28 & 0.87 & 2.83 & 1.82 & 1.08 & 5.68 \\
\hline & $3000 \mathrm{~m}^{2}$ 以上 & 12.11 & & 2.21 & 4.82 & 0.96 & 1.01 & 3.18 & 0.41 & 2.32 & 1.82 & 1.49 & 4.16 \\
\hline \multirow{3}{*}{ 計 } & $5000 \mathrm{~m}^{2}$ 以上 & 12.41 & 2.26 & 1.90 & 1.95 & 0.61 & 0.86 & 3.33 & 0.62 & 1.97 & 1.16 & 1.64 & 3.40 \\
\hline & $10000 \mathrm{~m}^{2}$ 以上 & 13.85 & & 0.92 & 6.77 & 0.46 & & 3.49 & & 2.07 & 1.92 & 1.95 & 4.21 \\
\hline & $30000 \mathrm{~m}^{2}$ 以上 & 7.28 & & & & & & 2.98 & & & & & 5.48 \\
\hline
\end{tabular}


表 7 建築設備工事費あたりの新築工事段階までの環境負荷原単位の回婂係数 $\mathrm{a}$ と確実度係数 $\mathrm{r}^{2}$

\begin{tabular}{|c|c|c|c|c|c|c|c|c|}
\hline & \multicolumn{2}{|c|}{$\begin{array}{c}\mathrm{CO}_{2} \text { 原単位 } \\
\left(\mathrm{kg}-\mathrm{CO}_{2} / \text { 千 }\right)\end{array}$} & \multicolumn{2}{|c|}{$\begin{array}{c}\mathrm{SO} \times \text { 原単位 } \\
\left(\mathrm{g}-\mathrm{SO}_{2} / \text { 千円 }\right)\end{array}$} & \multicolumn{2}{|c|}{$\begin{array}{c}\mathrm{NO} \times \text { 原単位 } \\
\left(\mathrm{g}-\mathrm{NO}_{2} / 千 \mathrm{M}\right)\end{array}$} & \multicolumn{2}{|c|}{$\begin{array}{c}\text { エネルギ一原単位 } \\
(\mathrm{MJ} / 千 \text { 开 })\end{array}$} \\
\hline & 傾き a & $r^{2}$ 值 & 傾き a & $\mathrm{r}^{2}$ 值 & 傾き a & $\mathrm{r}^{2}$ 值 & 傾き a & $\mathrm{r}^{2}$ 值 \\
\hline 電気設備 & 2.633 & 0.963 & 4.630 & 0.964 & 7.008 & 0.970 & 43.551 & 0.960 \\
\hline 空調設備 & 3.053 & 0.986 & 5.671 & 0.980 & 8.381 & 0.986 & 50.264 & 0.986 \\
\hline 衛生設備 & 3.823 & 0.972 & 6.258 & 0.966 & 10.865 & 0.970 & 60.300 & 0.973 \\
\hline 昇降機設備 & 5.118 & 1.000 & 8.139 & 1.000 & 14.197 & 1.000 & 83.166 & 1.000 \\
\hline 設備合計 & 3.101 & 0.979 & 5.420 & 0.980 & 8.519 & 0.977 & 50.433 & 0.980 \\
\hline
\end{tabular}

注 1：1990 年産業連関表による資本形成分を含み・海外波及分を含む環境負荷原単位

注 2: 直線回帰式 $\mathrm{y}\left(\mathrm{kg}-\mathrm{CO}_{2} / \mathrm{m}^{2}\right)=$ 傾き $\mathrm{a} \cdot \mathrm{x}$ （消費税別 1990 年価格の千円 $\left./ \mathrm{m}^{2}\right)$

注 3 : 確実度係数 $\mathrm{r}^{2}$ 値（ピアソンの積率相関係数を 2 乗した傎）

\section{2 建築設備のライフサイクル環境負荷原単位}

建筑設備の運転に伴う $\mathrm{CO}_{2}$ 排出量老除く、新築工事加建替工 事、修繥、改修工事、廃㶳処分に至るライフサイクル各段階での $\mathrm{CO}_{2}\left(\mathrm{LCCO}_{2}\right)$ 原単位を表 8 に示す。評洒対象期閒を 100 年とし、 その閒の年平均値を延床面積あたりで記载している。詳細な内訳 を表示しているのは、建替周期を 50 年とした場合であり、50 年 目に建築物自体が建替えられる際の建築設備の更新が 1 回分計上 されている。建物用途による $\mathrm{LCCO}_{2}$ 原単位の違いは、表 3〜6に 示した建築設備の新築工事段階までの $\mathrm{CO}_{2}$ 原単位の違いを反映し
ている。

建替周期が 35 年と 100 年の場合については、誌面の制約上、表 の最下欄に全建築設備の総合計のみを記載したが、建替周期と設 满細目每の更新周期の微妙なバランスが計算結果に影響している ものの、総合計としては極端な違いは見られない。

同様にして、建築設備のライフサイクル各段階での SOx 原単位、 NOx 原単位、エネルギ一原単位、コス卜原単位を、各々、表 9〜 12 に示す。建物用途・規模による原単位の違いは、ライフサイク ル $\mathrm{CO}_{2}$ の場合と同様の傾向を示している。

表 8 建築設備の延床面積あたり年平均ライフサイクル $\mathrm{CO}_{2}$ 排出量 $\left(\mathrm{kg}-\mathrm{CO}_{2} /\right.$ 年 $\left.^{\prime}\right)$ [1990 年産莱連関表による凟本形成・海外波及含む值]

\begin{tabular}{|c|c|c|c|c|c|c|c|c|c|c|c|c|c|c|}
\hline & 事務所 & $\begin{array}{l}\text { ホテル } \\
\text { •旅館 }\end{array}$ & 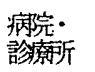 & 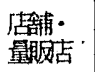 & $\begin{array}{l}\text { 小中 } \\
\text { 高校 }\end{array}$ & $\begin{array}{l}\text { 大学. } \\
\text { 高溥. }\end{array}$ & $\begin{array}{l}\text { 複合 } \\
\text { ヒルル }\end{array}$ & $\begin{array}{l}\text { 集荟 } \\
\text { 施知 }\end{array}$ & $\begin{array}{l}\text { 流通 } \\
\text { 施設 }\end{array}$ & 工場 & 独身尞 & 集合 \\
\hline \multirow{8}{*}{$\begin{array}{l}\text { 建 } \\
\text { 替 } \\
\text { 弇 } \\
5 \\
0 \\
0 \\
\text { 年 }\end{array}$} & \multirow{6}{*}{\begin{tabular}{|l} 
電 \\
気 \\
設 \\
備 \\
\end{tabular}} & 新築工事 & 1.16 & 1.05 & 0.84 & 0.55 & 0.67 & 0.79 & 0.91 & 0.93 & 0.29 & 0.54 & 0.68 & 0.36 \\
\hline & & 建替工事 & 1.16 & 1.05 & 0.84 & 0.55 & 0.67 & 0.79 & 0.91 & 0.93 & 0.29 & 0.54 & 0.68 & 0.36 \\
\hline & & 修縉 & 2.16 & 1.96 & 1.58. & 1.10 & 1.24 & 1.45 & 1.63 & 1.85 & 0.49 & 0.95 & 1.17 & 0.57 \\
\hline & & 改修工事 & 3.07 & 2.86 & 2.29 & 1.47 & 1.87 & 2.10 & 2.37 & 2.60 & 0.72 & 1.32 & 1.78 & 0.95 \\
\hline & & 廃寨処分 & 0.02 & 0.02 & $0: 01$ & 0.01 & 0.01 & 0.02 & 0.02 & 0.02 & 0.01 & 0.01 & 0.01 & 0.01 \\
\hline & & 合 計 & 7.57 & 6.94 & 5.56 & 3.68 & 4.46 & 5.15 & 5.84 & 6.33 & 1.80 & 3.36 & 4.32 & 2.25 \\
\hline & \multirow{6}{*}{$\begin{array}{l}\text { 空 } \\
\text { 調 } \\
\text { 設 } \\
\text { 備 }\end{array}$} & 新筑工事 & 1.30 & 1.19 & 0.95 & 0.52 & 0.73 & 1.19 & 0.98 & 0.96 & 0.20 & 0.53 & 0.47 & 0.12 \\
\hline & & 建替工事 & 1.30 & 1.19 & 0.95 & 0.52 & 0.73 & 1.19 & 0.98 & 0.96 & 0.20 & 0.53 & 0.47 & 0.12 \\
\hline & & 修織 & 3.05 & 2.82 & 2.17 & 1.21 & 1.68 & 2.76 & 2.31 & 2.28 & 0.44 & 1.23 & 1.12 & 0.29 \\
\hline 惠 & & 改修工事 & 4.90 & 4.39 & 3.65 & 1.92 & 2.75 & 4.50 & 3.67 & 3.61 & 0.76 & 1.98 & 1.78 & 0.45 \\
\hline 種 & & 廃棄処分 & 0.03 & 0.03 & 0.02 & 0.01 & $0: 02$ & 0.02 & 0.02 & 0.02 & 0.00 & 0.01 & 0.01 & 0.00 \\
\hline 別 & & 合 計 & 10.58 & 9.62 & 7.74 & 4.18 & 5.91 & 9.66 & 7.96 & 7.83 & 1.60 & 4.28 & 3.85 & 0.98 \\
\hline \multirow{6}{*}{ 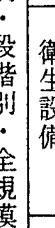 } & & 新築工事 & 0.71 & 1.38 & 1.28 & 0.45 & 0.62 & 0.56 & 0.77 & 0.76 & 0.20 & 0.38 & 1.04 & 0.80 \\
\hline & 衛. & 建替工事 & 0.71 & 1.38 & 1.28 & 0.45 & 0.62 & 0.56 & 0.77 & 0.76 & 0.20 & 0.38 & 1.04 & 0.80 \\
\hline & 生 & 修 䌜 & 1.55 & 3.12 & 2.82 & 0.94 & 1.37 & 1.25 & 1.67 & 1.69 & 0.44 & 0.85 & 2.31 & 1.73 \\
\hline & $\begin{array}{l}\text { 借 } \\
\text { 備 }\end{array}$ & 改修I事 & 2.65 & 5.24 & 4.66 & 1.61 & 2.19 & 1.99 & 2.97 & 2.66 & 0.69 & 1.35 & 4.11 & 3.26 \\
\hline & & 廃棄処分 & 0.03 & 0.06 & 0.06 & 0.02 & 0.03 & 0.03 & 0.04 & 0.04 & 0.01 & 0.02 & 0.05 & 0.04 \\
\hline & & 合. 計 & 5.65 & 11.18 & 10.10 & 3.47 & 4.83 & 4.39 & 6.22 & 5.91 & 1.54 & 2.98 & 8.55 & 6.63 \\
\hline 笑乎 & 暴 & 新築工事 & 0.11 . & 0.03 & 0.02 & 0.05 & 0.01 & 0.02 & 0.03 & 0.01 & 0.03 & 0.02 & 0.01 . & 0.04 \\
\hline \multirow{5}{*}{ 蛋 } & 番 & 建替工事. & 0.11 & 0.03 & 0.02 & 0.05 & 0.01 & 0.02 & 0.03 & 0.01 & 0.03 & 0.02 & 0.01 & 0.04 \\
\hline & 機 & 修 繯 & 0.23 & 0.06 & 0.05 & 0.10 & 0.02 & 0.04 & 0.06 & 0.02 & 0.06 & 0.03 & 0.03 & 0.09 \\
\hline & 設 & 改修工事 & 0.23 & 0.06 & 0.05 & 0.10 & 0.02 & 0.04 & 0.06 & 0.02 & 0.06 & 0.03 & 0.03 & 0.09 \\
\hline & 備 & 廃㟟処分 & 0.00 & 0.00 & 0.00 & 0.00 & 0.00 & 0.00 & 0.00 & 0.00 & 0.00 & 0.00 & 0.00 & 0.00 \\
\hline & & & 0.68 & 0.18 & 0.14 & 0.30 & 0.06 & 0.12 & 0.18 & 0.06 & 0.18 & 0.10 & 0.08 & 0.26 \\
\hline \multirow{6}{*}{\multicolumn{2}{|c|}{$\begin{array}{c}\text { 建替 } \\
\text { 周期 } \\
50 \text { 年 } \\
\text { 槼 } \\
\text { 模別 } \\
\text { 合計 }\end{array}$}} & $1000 \mathrm{~m}^{2}$ 末满 & 16.55 & 28.57 & 21.95 & 17.05 & 5.49 & 16.34 & 15.05 & .25 .24 & 11.89 & $16 . \overline{49}$ & 17.58 & 12.86 \\
\hline & & $1000 \mathrm{~m}^{2}$ 以上 & 17.72 & 29.64 & 26.36 & 12.75 & 14.16 & 21.37 & 15.13 & 18.73 & 6.13 & 9.53 & 16.02 & 10.63 \\
\hline & & $3000 \mathrm{~m}^{2}$ 以上 & 19.81 & & 25.03 & 12.91 & 17.74 & 17.03 & 16.48 & 28.34 & 4.34 & 10.61 & 15.34 & 9.92 \\
\hline & & $5000 \mathrm{~m}^{2}$ 以上 & 23.62 & 18.09 & 22.85 & 7.71 & 14.47 & 18.90 & 17.63 & 17.02 & 4.59 & 11.57 & 17.95 & 9.19 \\
\hline & & $10000 \mathrm{~m}^{2}$ 以上 & 27.02 & & 19.07 & 7.92 & 5.18 & & 19.06 & & 4.59 & 5.95 & 18.47 & 9.85 \\
\hline & & $30000 \mathrm{~m}^{2}$ 以上 & 28.58 & & & & & & 21.02 & & & & & 6.42 \\
\hline \multirow{3}{*}{\multicolumn{2}{|c|}{$\begin{array}{l}\text { 全規 } \\
\text { 模. } \\
\text { 合計 }\end{array}$}} & 建替周期 50年 & 24.48 & 27.92 & 23.54 & 11.63 & 15.26 & 19.32 & 20.20 & 20.13 & 5.12 & 10.72 & 16.80 & 10.12 \\
\hline & & 建替周期 35 年 & 23.44 & 27.16 & 22.99 & 11.17 & 14.81 & 18.64 & 19.45 & 19.49 & 4.87 & 10.26 & 16.44 & 9.91 \\
\hline & & 建替周期 100 年 & 24.09 & 26.82 & 22.82 & 11.27 & 14.80 & 18.90 & 19.73 & 19.60 & 4.98 & 10.38 & 16.31 & 9.61 \\
\hline
\end{tabular}

※建築設備の運転 (エネルギー消費) に伴う $\mathrm{CO}_{2}$ 排出量を除く。また、廃衰処分には片道 $30 \mathrm{~km}$ の搬出に伴う $\mathrm{CO}_{2}$ 排出量のみを計上。 


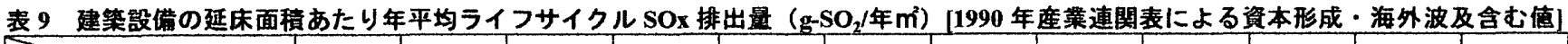

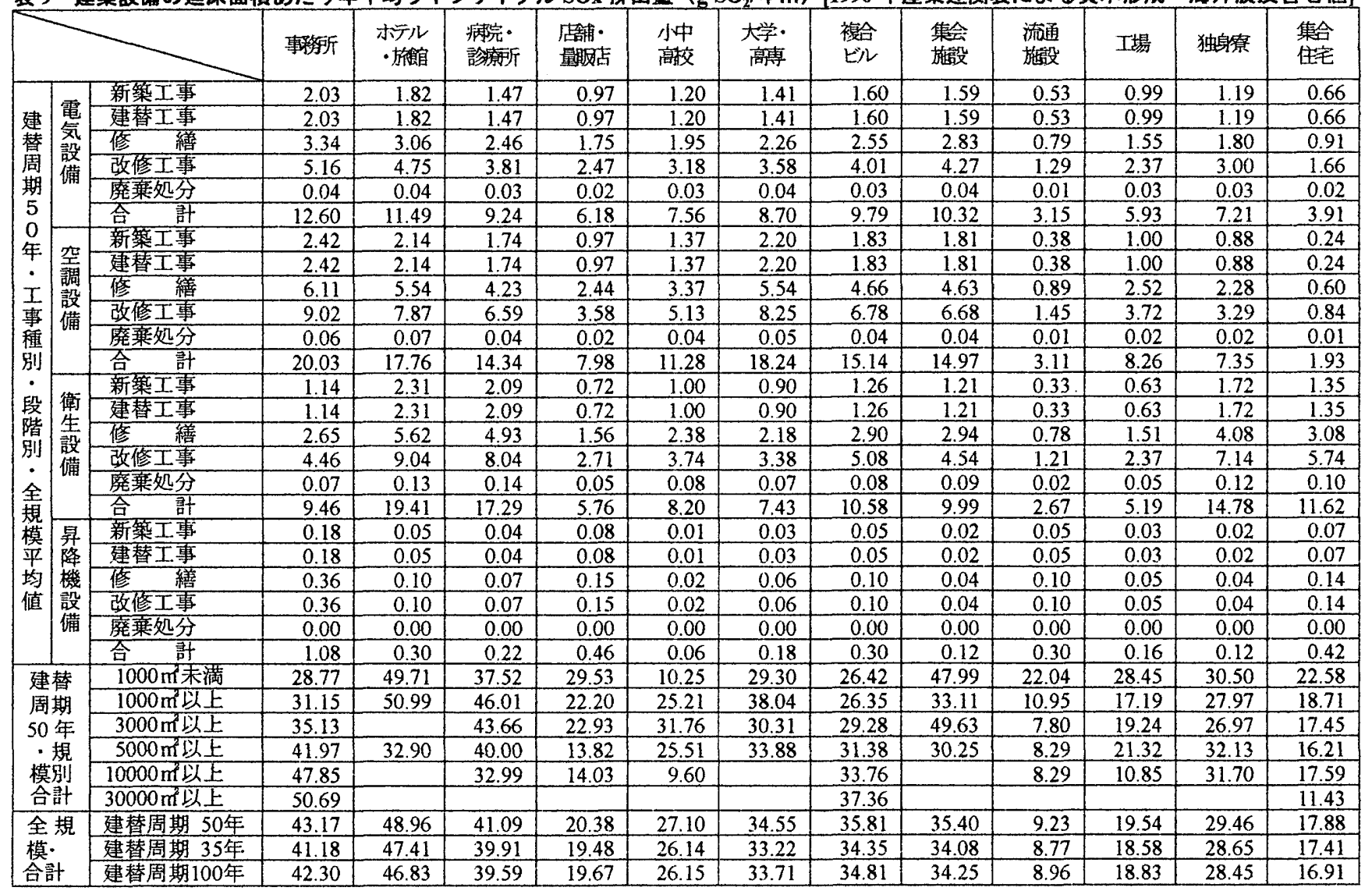

※建築設備の運転 (エネルギー消費) に伴う SOx 排出量を除く。また、廃重処分には片道 $30 \mathrm{~km}$ の搬出に伴う SOx 排出量のみを計上。

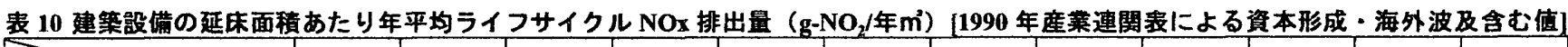

\begin{tabular}{|c|c|c|c|c|c|c|c|c|c|c|c|c|c|c|}
\hline & 事務所 & $\begin{array}{l}\text { ホテル } \\
\text { •施館 }\end{array}$ & $\begin{array}{l}\text { 病院- } \\
\text { 馀䤃斤 }\end{array}$ & 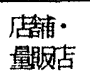 & $\begin{array}{l}\text { 小中 } \\
\text { 高校 }\end{array}$ & $\begin{array}{c}\text { 大学. } \\
\text { 高溥 }\end{array}$ & $\begin{array}{l}\text { 複合 } \\
\text { ビル }\end{array}$ & $\begin{array}{l}\text { 集会 } \\
\text { 施钤 }\end{array}$ & $\begin{array}{l}\text { 流通 } \\
\text { 施能 }\end{array}$ & 工場 & 独身寮 & $\begin{array}{l}\text { 集合 } \\
\text { 住宅 }\end{array}$ \\
\hline \multirow{6}{*}{$\begin{array}{c}\text { 建 } \\
\text { 簮 } \\
\text { 空 } \\
\text { 期 } \\
5\end{array}$} & \multirow{6}{*}{ 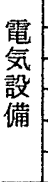 } & 新築工事 & 3.11 & 2.76 & 2.23 & 1.46 & 1.77 & 2.12 & 2.43 & 2.43 & 0.78 & 1.45 & 1.80 & 0.97 \\
\hline & & 建替工事 & 3.11 & 2.76 & 2.23 & 1.46 & 1.77 & 2.12 & 2.43 & 2.43 & 0.78 & 1.45 & 1.80 & 0.97 \\
\hline & & & 5.35 & 4.84 & 3.90 & 2.73 & 3.03 & 3.56 & 4.03 & 4.53 & 1.22 & 2.36 & 2.85 & 1.39 \\
\hline & & 改修工事 & 8.02 & 7.38 & 5.92 & 3.81 & 4.83 & 5.49 & 6.19 & 6.69 & 1.93 & 3.52 & 4.65 & 2.52 \\
\hline & & 廃裹処分 & 0.09 & 0.09 & 0.07 & 0.04 & 0.06 & 0.08 & 0.08 & 0.09 & 0.03 & 0.06 & 0.07 & 0.04 \\
\hline & & 小 計 & 19.68 & 17.83 & 14.35 & 9.50 & 11.46 & 13.37 & 15.16 & 16.17 & 4.74 & 8.84 & 11.17 & 5.89 \\
\hline \multirow{6}{*}{\multicolumn{2}{|c|}{$\begin{array}{l}\text { 年 } \\
\text { 京 } \\
\text { 事 } \\
\text { 種 } \\
\text { 放 }\end{array}$}} & 新築工事 & 3.56 & 3.30 & 2.60 & 1.41 & 2.02 & 3.26 & 2.67 & 2.66 & 0.54 & 1.46 & 1.28 & 0.35 \\
\hline & & 建替工事 & 3.56 & 3.30 & 2.60 & 1.41 & 2.02 & 3.26 & 2.67 & 2.66 & 0.54 & 1.46 & 1.28 & 0.35 \\
\hline & 䛋 & 修繥 & 8.47 & 7.96 & 6.00 & 3.36 & 4.71 & 7.72 & 6.41 & 6.38 & 1.22 & 3.45 & 3.12 & 0.83 \\
\hline & 借 & 改修工事 & 13.25 & 12.13 & 9.87 & 5.19 & 7.58 & 12.27 & 9.90 & 9.82 & 2.05 & 5.42 & 4.78 & 1.24 \\
\hline & & 廃裹好分 & 0.13 & 0.15 & 0.09 & 0.05 & 0.08 & 0.12 & 0.09 & 0.10 & 0.02 & 0.05 & 0.04 & 0.01 \\
\hline & & 小 計 & 28.97 & 26.84 & 21.16 & 11.42 & 16.41 & 26.63 & 21.74 & 21.62 & 4.37 & 11.84 & 10.50 & 2.78 \\
\hline \multirow{4}{*}{$\begin{array}{l}\text { 段 } \\
\text { 階 } \\
\text { 別 } \\
\text {. }\end{array}$} & \multirow{6}{*}{\begin{tabular}{|l} 
衛 \\
生 \\
設 \\
備
\end{tabular}} & 新築工事 & 1.99 & 3.97 & 3.59 & 1.25 & 1.78 & 1.62 & 2.19 & 2.13 & 0.56 & 1.09 & 3.01 & 2.32 \\
\hline & & 建替工事 & 1.99 & 3.97 & 3.59 & 1.25 & 1.78 & 1.62 & 2.19 & 2.13 & 0.56 & 1.09 & 3.01 & 2.32 \\
\hline & & 修縤 & 4.39 & 9.01 & 7.99 & 2.64 & 3.95 & 3.63 & 4.77 & 4.80 & 1.26 & 2.44 & 6.69 & 5.04 \\
\hline & & 改修I事 & 7.64 & 15.33 & 13.46 & 4.61 & 6.46 & 5.89 & 8.65 & 7.69 & 2.00 & 3.97 & 12.17 & 9.70 \\
\hline$\dot{1}$ & & 廃粪処分 & 0.17 & 0.29 & 0.31 & 0.10 & 0.17 & 0.16 & 0.18 & 0.20 & 0.05 & 0.10 & 0.27 & 0.22 \\
\hline 垷 & & 小 計 & 16.18 & 32.57 & 28.94 & 9.85 & 14.14 & 12.92 & 17.98 & 16.95 & 4.43 & 8.69 & 25.15 & 19.60 \\
\hline 模 & & 新筑工事 & 0.31 & 0.09 & 0.06 & 0.13 & 0.02 & 0.05 & 0.09 & 0.03 & 0.09 & 0.04 & 0.04 & 0.12 \\
\hline \multirow{5}{*}{\multicolumn{2}{|c|}{ 直 }} & 建替工事 & 0.31 & 0.09 & 0.06 & 0.13 & 0.02 & 0.05 & 0.09 & 0.03 & 0.09 & 0.04 & 0.04 & 0.12 \\
\hline & 降 & 修 縉 & 0.63 & 0.17 & 0.13 & 0.27 & 0.04 & 0.10 & 0.18 & 0.07 & 0.17 & 0.09 & 0.07 & 0.25 \\
\hline & 機 & 改修工事 & 0.63 & 0.17 & 0.13 & 0.27 & 0.04 & 0.10 & 0.18 & 0.07 & 0.17 & 0.09 & 0.07 & 0.25 \\
\hline & 熟 & 廃襄処分 & 0.01 & 0.00 & 0.00 & 0.00 & 0.00 & 0.00 & 0.00 & 0.00 & 0.00 & 0.00 & 0.00 & 0.00 \\
\hline & & 小 計 & 1.89 & 0.52 & 0.38 & 0.80 & 0.12 & 0.30 & 0.54 & 0.20 & 0.52 & 0.26 & 0.22 & 0.74 \\
\hline \multirow{6}{*}{\multicolumn{2}{|c|}{$\begin{array}{l}\text { 建替 } \\
\text { 周期 } \\
50 \text { 年 } \\
\text { - 規 } \\
\text { 模別 } \\
\text { 合計 }\end{array}$}} & $1000 \mathrm{~m}^{2}$ 末満 & 45.38 & 78.75 & 59.70 & 46.26 & 14.64 & 44.81 & 41.59 & 68.48 & 32.88 & 45.60 & 50.26 & 36.62 \\
\hline & & $1000 \mathrm{~m}^{2}$ 以上 & 48.36 & 82.76 & 72.85 & 34.71 & 39.13 & 58.63 & 41.76 & 50.96 & 17.02 & 26.37 & 44.72 & 30.45 \\
\hline & & $3000 \mathrm{~m}^{2}$ 以上 & 54.04 & & 68.53 & 34.79 & 48.15 & 46.74 & 45.82 & 78.91 & 11.87 & 29.09 & 43.22 & 28.43 \\
\hline & & $5000 \mathrm{~m}^{2} \mathrm{~L}$ & 64.19 & 50.83 & 63.79 & 20.89 & 39.91 & 52.33 & 48.42 & 46.34 & 12.52 & 32.17 & 50.04 & 26.34 \\
\hline & & $10000 \mathrm{~m}^{2}$ 以上 & 73.37 & & 52.65 & 21.42 & 14.18 & & 51.63 & & 12.51 & 16.27 & 51.45 & 28.09 \\
\hline & & $30000 \mathrm{~m}^{3}$ 以上 & 78.02 & & & & & & 56.97 & & & & & 17.97 \\
\hline \multirow{3}{*}{\multicolumn{2}{|c|}{$\begin{array}{l}\text { 全 規 } \\
\text { 模. } \\
\text { 合計 }\end{array}$}} & 建替周期 50 年 & 66.72 & 77.76 & 64.83 & 31.57 & 42.13 & 53.22 & 55.42 & 54.94 & 14.06 & 29.63 & 47.04 & 29.01 \\
\hline & & 建替周期 35年 & 63.82 & 75.69 & 63.27 & 30.35 & 40.87 & 51.36 & 53.35 & 53.11 & 13.37 & 28.36 & 46.00 & 28.42 \\
\hline & & 建替周期100年 & 65.35 & 74.26 & 62.46 & 30.51 & 40.61 & 51.81 & 53.85 & 53.12 & 13.66 & 28.53 & 45.42 & 27.42 \\
\hline
\end{tabular}

※建築設備の運転（エネルギー消費）に伴う NOx 排出量を除く。また、廃棄処分には片道 $30 \mathrm{~km}$ の搬出に伴う NOx排出量のみを計上。 


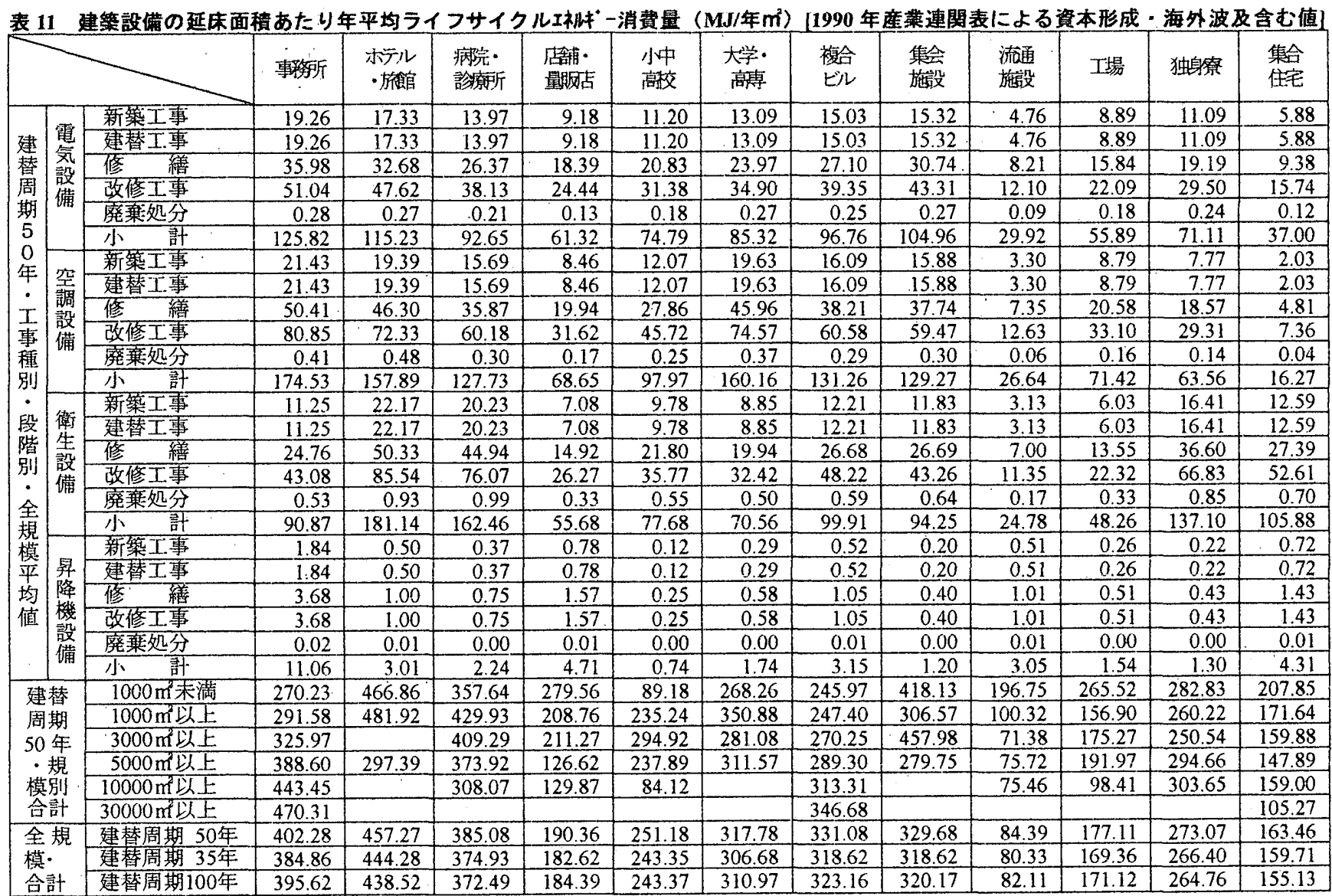

※建築設備の運転に伴うエネルギー消費量を除く。また、廃㐮処分には片道 $30 \mathrm{~km}$ の搬出に伴うエネルギー消費量のみを計上。

表 12 建築設備の延床面皘あたり年平匀ライフサイクルコスト（千円 $/$ 年 $\left.\mathrm{m}^{2}\right)$

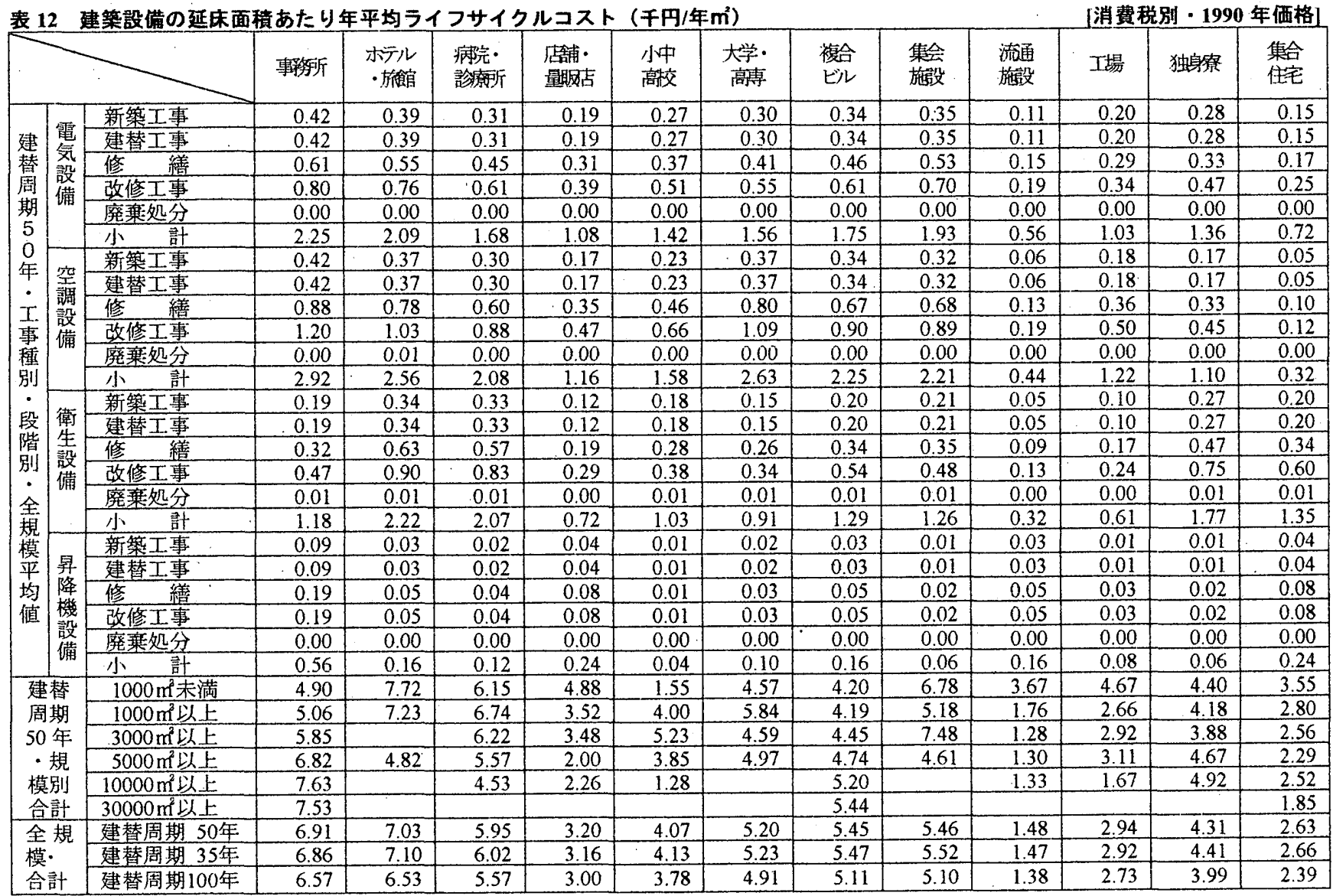

※ 建築設備の運転に伴うエネルギー費を除く。また、廃辑処分には片道 $30 \mathrm{~km}$ の搬出費用のみを計上。 
表 13 建築設借工事费あたりのライフサイクル環境負荷原単位の回㷌俰数 $\mathrm{a}$ と確実度係数 $\mathrm{r}^{2}$

\begin{tabular}{|c|c|c|c|c|c|c|c|c|}
\hline & \multicolumn{2}{|c|}{$\begin{array}{c}\mathrm{LCCO}_{2} \text { 原単位 } \\
\left(\mathrm{kg}-\mathrm{CO}_{2} \text { /年・千円 }\right) \\
\end{array}$} & \multicolumn{2}{|c|}{$\begin{array}{c}\mathrm{LCSO} \times \text { 原単位 } \\
\left(\mathrm{g}-\mathrm{SO}_{2} / \text { 年. 干界) }\right.\end{array}$} & \multicolumn{2}{|c|}{$\begin{array}{l}\text { LCNO } x \text { 原単位 } \\
\left(\mathrm{g}-\mathrm{NO}_{2} / \text { 年·千开 }\right)\end{array}$} & \multicolumn{2}{|c|}{$\begin{array}{c}\text { LCE原単位 } \\
(\mathrm{MJ} / \text { 年·千円) }\end{array}$} \\
\hline & 傾き a & $\mathrm{r}^{2}$ 值 & 傾き a & $\mathrm{r}^{2}$ 值 & 傾き a & $\mathrm{r}^{2}$ 值 & 傾き a & $r^{2}$ 徝 \\
\hline 電気設備 & 0.165 & 0.936 & 0.275 & 0.935 & 0.425 & 0.942 & 2.732 & 0.934 \\
\hline 空調設備 & 0.247 & 0.936 & 0.466 & 0.977 & 0.678 & 0.984 & 4.076 & 0.983 \\
\hline 衛生設備 & 0.300 & 0.936 & 0.513 & 0.953 & 0.869 & 0.956 & 4.801 & 0.960 \\
\hline 吿降機設備 & 0.290 & 0.985 & 0.461 & 0.985 & 0.808 & 0.985 & 4.722 & 0.985 \\
\hline 設備合計 & 0.229 & 0.971 & 0.402 & 0.970 & 0.629 & 0.966 & 3.740 & 0.972 \\
\hline
\end{tabular}

注 1：1990 年産業連関表による資本形成分を含み・海外波及分を含む環境負荷原単位

注 2 : 直線回帰式 $\mathrm{y}\left(\mathrm{kg}-\mathrm{CO}_{2} /\right.$ 年・ $\left.\mathrm{m}^{2}\right)=$ 傾き $\mathrm{a} \cdot \mathrm{x}$ (消費税別 1990 年価格の千円 $\left./ \mathrm{m}^{2}\right)$

注 3 : 確実度係数 $\mathrm{r}^{2}$ 值（ピアソンの積率相関俰数を 2 乗した値）

全 12 建物用途・全規模・建替周期（30 年、50 年、100 年）の データを対象として、延床面積あたりの設備工事費（消費税別・ 1990 年価格）とライフサイクル環境負荷原単位（ただし、設備運 用段階を除く)の回㷌分析を行った結果を表 13 に示す。確実度 係数 $\mathrm{r}^{2}$ 值 (ピアンンの積率相関係数を 2 乗した值) は、いずれの 場合も 0.93 以上であり、建築設備のライフサイクル嘼境負荷原単 位は、建物用途・建物規模・建替周期によらず、各設備工事費に 比例することを示している。

\section{4. まとめ}

建築物は、多種多様な製品とサービスによって建設・運用され る一品生産品であり、設計初期段階に使える寒用的な LCA 手法と 環境負荷原単位の整備が求められている。本報では、建物規模別 工事実績統計、1990 年産業連関表等の各種統計データを利用して、 12 種類の建物用途（事務所、ホテル、病院、店舗、小中高校、大 学、複合ビル、集会施設、流通施設、工場、独身寮、集合住宅) について、電気・空調・衛生・昇降機設備の $\mathrm{LCCO}_{2} 、 \mathrm{LCSO} \mathrm{x}$ 、 LCNO $x 、 L C C 、 L C E$ 原単位の分析結果を示した。今後、建築工 事の原単位を整備してゆく予定である。

\section{部 辞}

本研究の遂行にあたり、(財)電力中央研究所の内山洋司氏、本 藤祐樹氏より産業部門別直接環境負荷データの提供をはじめ、さ まざまなご協力を頂いた。また、(社)日本建筑学会地球環境委員 会 LCA 指針策定小委員会(石福 昭主查)、(社)空気調和・衛生工 学会地球環境委員会(鎌田元康委貣長)、建設大臣官房官庁営繬部 環境負荷の少ない官仃施設の整備手法の検討委買会(松尾 陽委 員長、坂本雄三専門委員長)、(財)住宅・建築省エネルギー機構 IEA/Annex31 国内委員会(岡 建雄委員長)、(社)産業環境管理協会 LCA 実務入門編集委員会(稲葉 敦委員長)では、委員の方々より 多くの示唆を頂いた。

\section{参考文萳}

1）伊香賀俊治、外岡 豊：事務所ビルの設備のライフサイクル羁境負荷 原単位、日本建築学会計画系論文集 No.529、2000.3（掍㳦予定）

2) 日本建筑学会建筑之地球環境委員会特別研究委員会：建築が地球瓄境

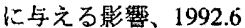

3）日本建策学会地球璪境委員会ライフサイクル $\mathrm{CO}_{2}$ 小委員会 : ライフサ イクル $\mathrm{CO}_{2}$ で建物を測る、1996.3

4）日本建策学会地球環境委員会 LCA 指針策定小委員会：建物の LCA 指 針 (案) 、1998.11

5) 日本建築学会地球環境委員会 LCA 指針策定小委員会 : 建物の LCA 指 針 (案)、CD-ROM 付、1999.11

6）竹林芳久、岡 建雄、紺矢哲夫：産業連関表に上る建筑物の評価、そ の 2 事務所建築の建設による環境への影䇾、日本建築学会計画系論文 報告集No431、1992.1

7）跉木道哉、岡 建雄、岡田圭史、矢野謙禎：産業連関表に上る建等物 の評価、その 4 事務所ビルの建設・運用に関かるエネルギー消費量、 二酸化炭素排出量、日本建築学会計画系諭文報告集NNo476、pp.37 43、 1994.9

8）林英明、岡 建雄、小玉祐一郎：1990 年表によるエ视诔”一消费量と炭素排 出量の原単位、産業道関表による建娼物の評伍（その 5 )、日本建榮学 会計画系論文集 No.511、pp.75 81、1998.9

9）酒井寛二、漂䗁 昇、相賀 洋、下山真人：建築物のライフサイクル 二酸化宸素排出量とその抑制方策に関する研究、日本建築学全計画系 論文集 No.484、pp.105 112、1996.6

10）传藤正椙、岡田幸雄：基本設計段階でのライフサイクル評洒システム に関する研究、その 1 。概算見積システムと建設分の $\mathrm{CO}_{2}$ 排出量の評 価システムの連携、日本建築学会大会学術講演梗概集 (㻴境系)、pp.885 $\sim 886,1996.9$

11) 本藤祐鼔、外岡 豊、内山洋二: 産業連関表を用いた我が国の生産活 動に伴う境負荷の実態分析、電力中央研究所報告 Y97017、1998.6

12）伊愁賀俊治、外岡 豊、本藤祐樹、内山洋司：建築物の $\mathrm{LCA}-\mathrm{CO}_{2}$ と 大気污染排出評価、第 15 回エネルギーシステム・経济・環境コンファ レンス隣演論文集、pp.425 430、1999.1

13) 総務庁: 平成 2 年産業連関萂、(財) 全国統計協会連合会、1994.3

14) 建設省建設経済局監修: 平成 2 年建設部門分析用产業連関表、(財)建設 物洒媩查会、1995.1

15) 貄設大臣官房官庁営䌁部監修：建築物のライフサイクルコスト、(財) 経済調查会、1993

16) (社)建築・設㣁維持保全推進協会螎著：ビルディングLCビジネス百科、 オーム社、1996.6

17）建設工業経営研究会螎著 : 建築工事原価分析情報、大成出版社、1996.4、 1997.4、1998.4

18）建設工業経営研究会編著：標淮建築費指数及び施工単価月報、大成出 版社、1991.1 1996.1

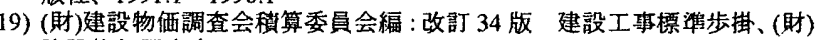
建設物俩調查会, 1997.9

20）建設大臣官房官庁営橧部監修: [平成 9 年基淮]建設省建築工事糟算基进 の解説、(財)建筑コスト管理システ公研究所、1998.2

21）建設大臣官椖官庁営縓部監修、グリーン庁舎計画指針及び同解説 平 成 11 年、(社) 公共建案協会、1999.4

22）品気調和・衛生工学会地球骤境委員会：建築設備と地球罜境に関する 研究、1999.3

23）(社）産業環境管理協会 LCA 実務入門編集委員会編：LCA 実務入門、 丸䍰、1998.8

（2000年 1 月 10 日原稿受理， 2000 年 2 月 17 日採用决定） 